\title{
How to shore up public finances against the unexpected
}

Written by: Catherine Gamper, OECD Public Governance Directorate

Last update: 30 October 2019

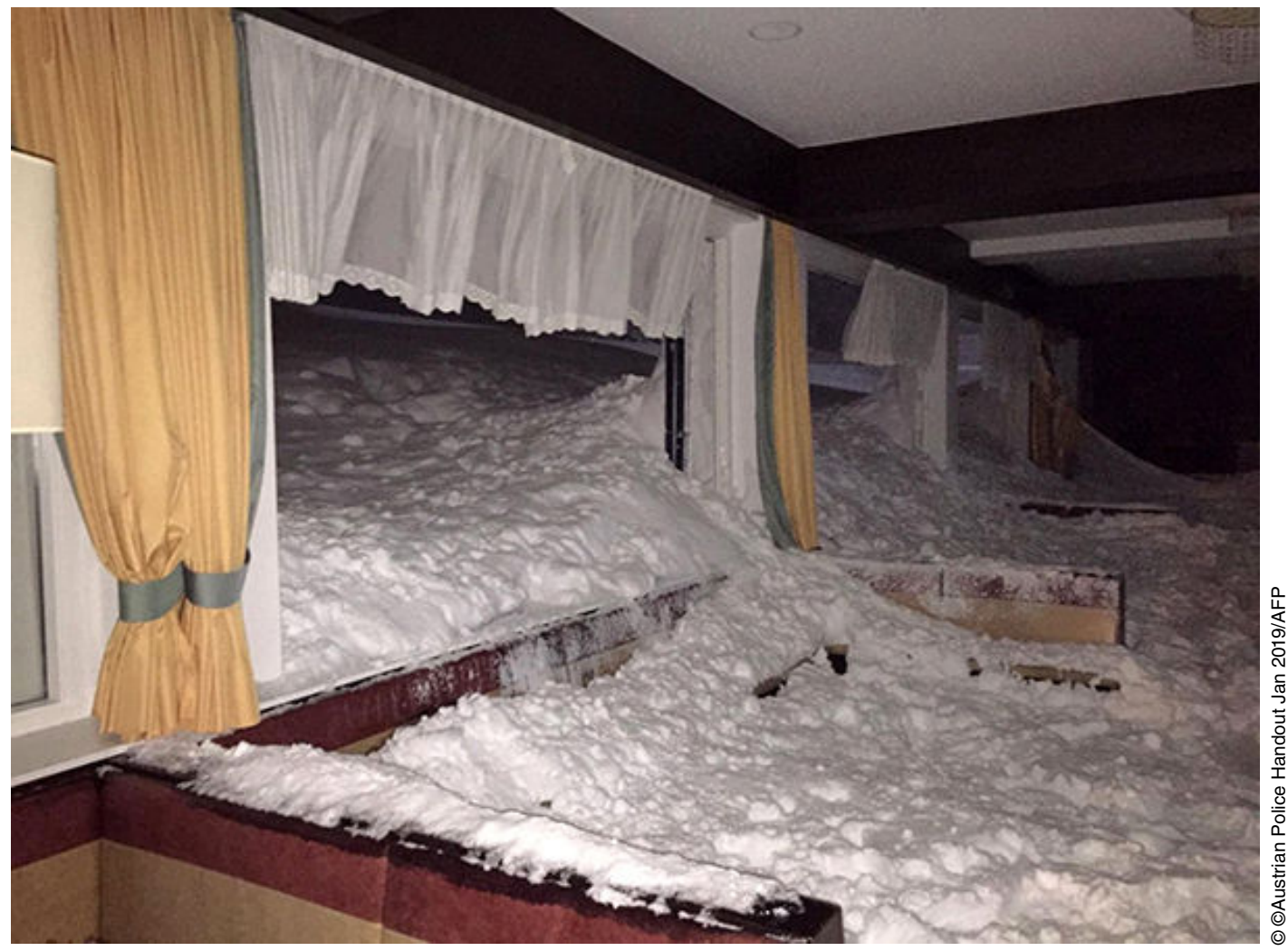

How to shore up public finances against the unexpected

Natural hazards can lead to costly disasters, which is why public authorities must work hard to reduce risks and to be prepared financially. What can governments do to strengthen their fiscal resilience?

One morning in 1988, bundled up in my winter clothes, I was ready to brave another dark and chilly winter walk to school, when the telephone rang. My mum gave us the unexpected good news: no school today. But we soon realised that the news was not good at all. There was no school because a huge avalanche had 
buried half of our village. While some of my childhood friends were unharmed and a few had woken up to snow falling onto their beds, others sadly had lost loved ones.

Growing up in Austria, a small country surrounded by snow-capped mountains and endowed with large bodies of water, I was always acutely aware of the looming climate risks. Indeed, $13 \%$ of Austrians are at risk of avalanches, torrents or flooding, and climatic changes are expected to increase Austria's exposure to such events.

While these adverse weather events have contributed to Austria's long-standing policy of investing in disaster risk reduction, disaster-related costs for the government are still significant. The average annual loss estimate of $€ 210$ million may not sound like that much, but it includes significant, extreme events such as the 2003 floods, which caused an estimated $€ 3$ billion in damages, for which compensation for which was mostly paid for by the government.

Austria is not alone facing such costs. Many OECD and non-OECD countries grapple with the massive impact of disasters on public finances. For example, in addition to the tragic loss of life, the 2011 Tohoku earthquake, tsunami and nuclear disaster in Japan contributed to a $2 \%$ economic contraction in the following quarter of that year and led to a surge in additional central government spending for recovery and reconstruction in 2012. That's equivalent to $8 \%$ of Japan's GDP and over $20 \%$ of its general government budget.

The fiscal impact of disasters isn't only linked to their size. Although one local disaster is unlikely to affect national accounts, frequent smaller, local incidents can have a significant fiscal and economic impact in the same way major disasters do.

Whatever the size of the incident, governments often assume the lion's share of recovery and reconstruction costs. This may include repairing damaged public assets, giving immediate relief to households and assisting people with reconstruction, as well as providing support to help keep businesses open. And while public expenditures go up as a result, government revenues may shrink due to a slowdown in economic activity. Together, this has a significant impact on their balance sheet.

So what can governments do to ensure fiscal resilience? A recent OECD-World Bank report Fiscal Resilience to Natural Disasters offers practical lessons and insights into how governments manage disaster-related contingent liabilities and suggests ways to control them better and reduce their fiscal impacts in the future. 


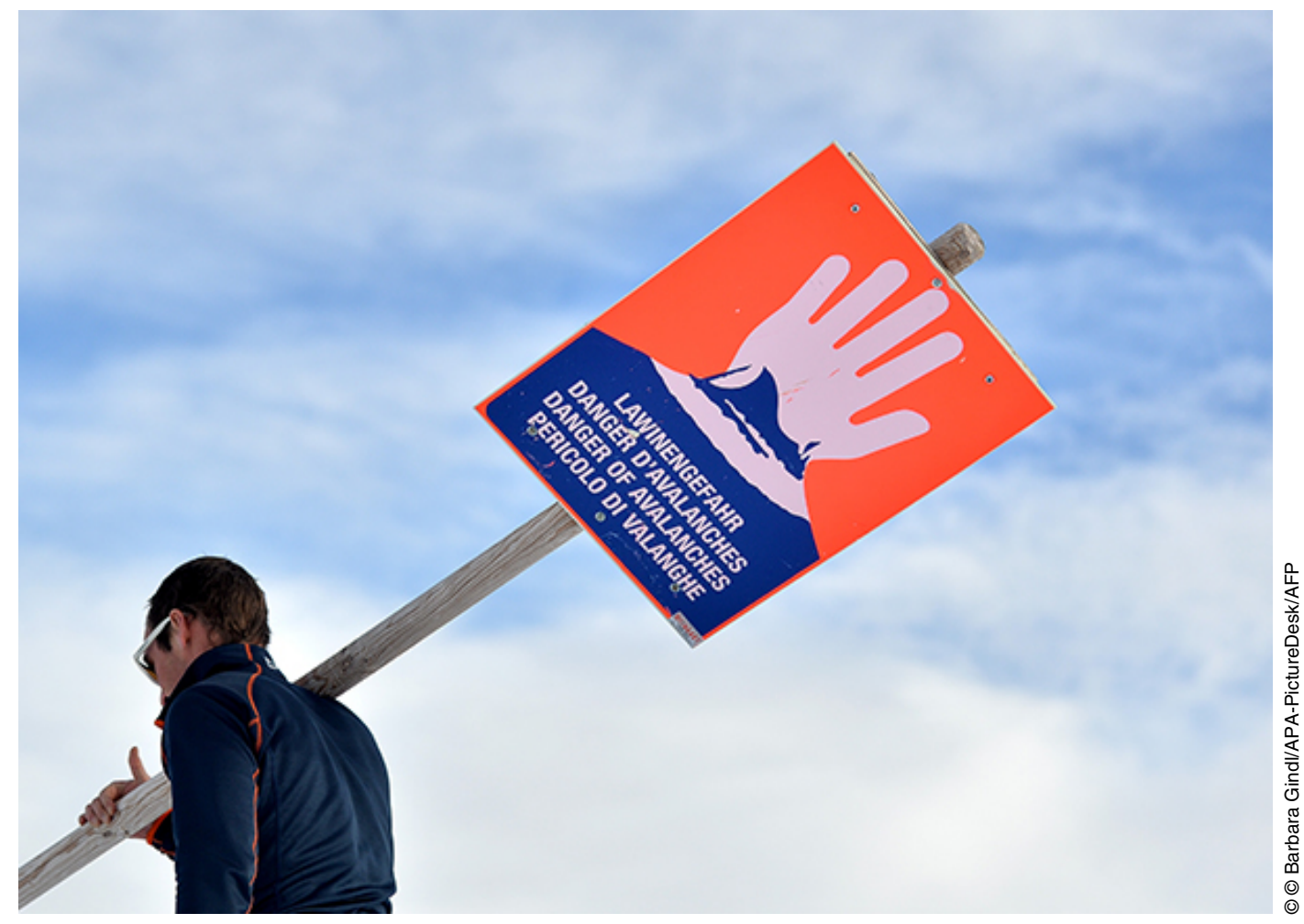

The report finds that setting explicit rules about the government's commitments to compensate for disaster losses can effectively limit its liabilities, as is the case in Japan, for instance. In other countries, such as Colombia, only very general rules about public compensation increase reliance on the government's financial aid and decreases the incentives of affected stakeholders to act upstream and invest in protecting their own assets.

The report also finds that countries should be better informed about the potential size of the fiscal impacts disasters can have. Even though a lot of data is available in many countries, they are not always compiled to estimate potential fiscal impacts. Fiscal risk statements may contain a qualitative mention, such as “significant, but remote", so as to draw policy makers' attention to anticipating and managing disaster risks more effectively

But governments can do more and there is still much scope for greater control over disaster-related liabilities, for instance, by improving the conditions upon which financial support for reconstruction is given.

Take another Austrian story: in response to a landslide disaster in 2015, the mayor of the affected community proudly announced that "the families who lost their homes have decided not to move anywhere else. And we will help them rebuild their homes exactly where they were."

While place, home and community are understandably important to people, this anecdote shows why contingent liabilities continue to rise. Risk reduction, and 
especially "building back better", should be an important part of measures for reducing government liabilities. Educating businesses and households about disaster risk and the role they have in strengthening their own resilience is also important. And to avoid repeatedly paying for the same preventable damage, governments may consider incentives, such as lowering damage reimbursement rates for repeated damage claims.

Disasters and extreme events seem to be higher now than during my schooldays, and could rise further, notably because of climate change. Governments will need to work harder to set clear rules for assistance and compensation for losses, in order to prevent disaster-related liabilities from causing a public finance disaster as well.

@OOECD Observer No 319 October 2019

\section{References}

OECD-World Bank (2019), Fiscal Resilience to Natural Disasters: Lessons from Country Experiences, OECD Publishing, Paris, see OECD iLibrary or http:// dx.doi.org/https://doi.org/10.1787/27a4198a-en

OECD (2018), Assessing the Real Cost of Disasters: The Need for Better Evidence, OECD Reviews of Risk Management Policies, OECD Publishing, Paris, see OECD iLibrary or http://dx.doi.org/https://doi.org/10.1787/9789264298798-en

OECD (2017), Boosting Disaster Prevention through Innovative Risk Governance: Insights from Austria, France and Switzerland, OECD Reviews of Risk Management Policies, OECD Publishing, Paris, see OECD iLibrary or http:// dx.doi.org/https://doi.org/10.1787/9789264281370-en. 